\title{
The Influence of Pressure, Opportunity and Rationalization on Academic Fraud of Vocational Student
}

\author{
Santi Susanti*, Dian Lestari \\ Faculty of Economics, State University of Jakarta, Rawamangun, 13220, East Jakarta, Indonesia
}

Copyright@2019 by authors, all rights reserved. Authors agree that this article remains permanently open access under the terms of the Creative Commons Attribution License 4.0 International License

\begin{abstract}
This study aims to determine the influence of pressure, opportunity, and rationalization on academic fraud for accounting vocational high school student. The methodology of this study is survey research applying the Triangle Fraud for academic fraud with a sample of 130 high school vocational students to understand better the reasons for their academic fraud using regression statistical analysis. The method that used in this research is a survey method with a correlation approach. This method was chosen according to the purpose of the study, namely knowing whether or not there is an influence of pressure, opportunity and rationalization on academic fraud. The result of this study showed that there is a significant relationship between pressure, opportunity, and rationalization with academic fraud and that there is a partial influence of pressure on academic fraud.
\end{abstract}

Keywords Pressure, Opportunity, Rationalization, Fraud Triangle, Academic Fraud

\section{Introduction}

Education is the most powerful weapon to change the world as Nelson Mandela said. Education brings a human being to become a complete human being, so that he can humanize other humans. The progress of a country can also be seen from how advanced the country is in managing the education system and producing whole people who are contextualized with the state of the country. Education also brings people to be wise beings in response to every problem that occurs in life, so he always tries to find solutions to the problem. The conclusion if we look deeper into education is very important in this life. However, in the process of realizing essential education as explained earlier, there are many problems that hinder the realization of education.
One of the most tarnishing and troubling problems in education is academic cheating. Education should occur through several channels. As stated in Law No. 20 of 2003 Article 13, paragraph 1, the education pathway consists of formal, non-formal and informal education. (KEMENAG, 2009). The formal education path is a path that the government requires to go through. According to the Act mentioned above, formal education is an educational pathway that is conducted through schools that have been provided by each country, for example in Indonesia there are elementary school (SD) education levels, junior high schools (SMP), high schools / vocational schools (SMA / $\mathrm{K})$, and college. At these levels of education, the education process is carried out.

In the context of the formal education path, the course of education at each level must be done through learning activities carried out in various ways, namely by the process of transfer of knowledge or teaching, assignments of tasks that must be completed by students in order to achieve the planned abilities. At the end, there is an assessment process carried out by holding examinations or tests for students. Students must go through the process well, but at that time problems also arise, namely how to make students go through the process well and also get good results. Therefore, there are widespread acts of academic fraud in order to get good results even though he is not going through a good process.

In a theory that explains the causes of fraud, namely the Fraud Triangle theory, there are three things that cause a person to commit fraud, namely pressure, opportunity, and rationalization. These things have been analyzed to prove the reasons for fraud, including academic cheating.

Academic cheating is rampant everywhere. In a study conducted by Collage Curres in the United States in 2012, it stated that 53 percent of students think cheating is not a big thing to be fussed about, and 34 percent of students admitted their parents never talked to them about cheating. Worse yet, 98 percent of students invited their friends to 
copy their assignments (Nurfuadah, 2012). The study revealed that what causes students to cheat is rationalization that cheating is not a big thing and there is also an opportunity to do things that are friends who give their assignments happily.

Then in 2013 more than 160 students of the law faculty at the University of Tasmania in Australia were caught cheating on the final examination of criminal and civil procedure procedures (NWK, 2013). In this case, academic cheating was carried out because students were under pressure to graduate from the course. Furthermore, academic cheating was also carried out by students of one of the most famous universities in the world namely Harvard University based on a survey conducted by at least 9\% of Harvard new students doing academic cheating namely cheating while doing assignments and homework. This was done because of the pressure that came from the tight competition between students when studying at Harvard (BBC, 2015). Those are some phenomena of academic fraud from countries in the world.

In Indonesia, academic cheating is also still rampant. Based on data from the Ministry of Education and Culture in 2013, there were 808 cases relating to lecturer plagiarism in order to pass the lecturer certification. Then there can be found many schools in Indonesia, especially in the implementation of the National Examination (UN) facilitating and providing opportunities by buying key answers so that students can graduate well so that they can bring good names to the school concerned.

Based on the facts that have been explained previously, the factors in Fraud Triangle namely pressure, opportunity and rationality as well as the low self-confidence of students, as well as maintaining the image of the school are very influential in the occurrence of academic fraud. The pressure factor appears in the form of guidance so that students have good grades in all subjects. Opportunity factors arise in the form of test supervisors' indecisiveness or weak academic fraud control systems. Rationalization factors arise due to the perception of people around that doing academic cheating is a natural and normal thing. The factor of maintaining the image of the school arises from the desire to keep the school from being considered good and many interested. Finally, the factors of students who are not confident are the causes of academic fraud.

Everyone has their own prices, and honesty is the most expensive price of a human being. Therefore, this act of academic fraud is very disturbing and has a very negative impact and damages the quality of human resources. If the behavior of academic cheating is allowed then the national education goals will be difficult to achieve.

\section{Objectives}

Academic cheating is very disturbing in the process of running education; the result of academic cheating not only slows the achievement of national education goals but also destroys the morality of the generation of the nation's children. According to Tipton, academic cheating is taking cognitive shortcuts by sending work for assessment that does not belong to itself. This academic cheating is also done to gain profit (Tipton, 2015). Fass also revealed that attempts to define academic dishonesty are often written in terms such as "taking unfair advantage from other students" or representing their words or ideas as separate problems (Bleeker, 2008). In addition, Kibler also noted that academic dishonesty usually triggers fraud and plagiarism which results in students' giving or receiving unauthorized assistance in academic training or receiving credit for work that is not their own work (Bleeker, 2008). Academic dishonesty can be categorized as academic cheating (Auer, 2017).

Meanwhile, The University of Maryland-Baltimore "Policy and Concerning Misconduct" (Kulakowski \& Chronister, 2006) defines "academic errors" as including and adding fabrication, falsification and plagiarism, all forms of behavior, including making reckless allegations, typographical errors, or wrong presentation, where the work of others is completely misinterpreted. (Halstead, 2017) also mentioned that academic cheating has many forms, such as plagiarism in doing assignments, cheating on exams, buying assignments from others, falsifying information and data, justifying one's duties. (Emerson, 2017) then argues that in the case of clinic practice, academic cheating consists of plagiarism, retrieval of tasks that have been submitted for the next task, falsification of patient data, lying in actions or words, and cheating or cheating in exams.

The cheating triangle or commonly called the Fraud Triangle is one method found by Donald R. Cressey (Singleton, 2006) a criminologist from the United States in 1973 to examine the causes of financial fraud committed by employees. In his research, Cressey interviewed 200 financial employees to test the reasons for financial fraud. As a result, the hypothesis that emerged from the interview stated that the reasons often used in fraud were; 1) There is pressure (usually called an indisputable push or need), 2) There are opportunities, and 3) There is rationalization (one's ethical decision) which is the reason why they commit fraud. Therefore, the hypothesis is known as the Triangle Fraud which contains 3 elements namely pressure, opportunity and rationalization. According to (Bleeker, 2008), this concept can also be used to test the occurrence of academic fraud.

Everyone has the pressure to live. These pressures cause a person to cheat. According to (K. Henn, 2009), the pressure is what can come from individual, group, or a combination of both. Whereas according to (L. June, 2013), the pressure is something that comes from the existence of financial needs such as medical bills, car insurance, alcohol or drug addiction, which lives beyond their ability, and others. Then according to (Singleton, 2006), pressure (or 
incentives, or motivation) refers to something that has happened in the personal life of a fraudster who creates the need for stressful funds and thus motivates him to steal.

Another statement to corroborate the forms of academic cheating is echoed by Dalton (Bleeker, 2008) which states that economic downsizing and increasing competition for employment and access to graduate and professional schools have pushed pressure for good grades and academic success among students University today.

Based on the pressure theory above, the writer uses an indicator from the study of Becker et al which was adopted from Gardner and Melvin (1983) to assess pressure as follows:

1). 1) Tasks that are too difficult and many,

2). 2) Students feel unable to meet graduation standards if they do not commit academic cheating,

3). 3) Exams that are too difficult,

4). 4) Students cannot manage time.

In academic cheating, fraudsters take advantage of the opportunities that exist to do so. Great opportunities as a result of weak supervision strongly support the occurrence of academic fraud. (K. Henn, 2009) states that opportunity means that the environment is in a condition such that deviations can occur. Then (L. June, 2013) reinforces that opportunity is the result of weak internal control due to poor management supervision, employees who believe that they will not be caught may be due to a position of trust. Furthermore, (E. Turvey, 2013) in his book added that the opportunity was experienced in the form and access to assets, people, information, and computer systems that enabled the person not only to cheat but hide it.

According to (K. Henn, 2009) rationalisation is the core of the decision-making process when it's time to choose "go" or "not go" to be achieved. So based on Stephen's definition, rationalisation became the executor of acts of academic fraud. Then (L. June, 2013) added that rationalisation is an important component in the case of conscience and justifies its actions. If we look at the definition of June, human conscience does not justify destructive behaviour but rationalisation becomes an important element in opposing this conscience. Furthermore, (Goldmann, 2010) has another definition of rationalisation, that is, rationalisation is a psychological process in which someone who has committed cheating assures himself that he considers it wrong, it will be "corrected". According to (Goldmann, 2010), the rationalisation arose because he felt he would correct his mistakes later.

The pressure felt by students is one of the driving factors that make students commit academic cheating. Great pressure, of course, makes students think how to find a quick way out of all the pressures they feel.

The explanation above is reinforced by the opinion of (Bleeker, 2008) which states that several reasons why some students cite cheating, for example, the level of laziness, pressure, and cynicism, are difficult to conceptualize or relate to the baby boomer generation.

Then (Simon, 2015) added that the pressure to win from a competency triggers errors, academic cheating, and other crimes. Furthermore, Mc Cabe (Brow, 2012) explained that the pressure of competition to be able to get a good position and get a good school leads to the decision to engage in various forms of academic dishonesty.

\section{Materials and Methods}

\subsection{Methodology}

The method used in this research is a survey method with a correlation approach. This method was chosen for the purpose of the study, namely knowing whether or not there is the influence of pressure, opportunity and rationalisation on academic fraud.

\subsection{Measurement}

Indicators of academic cheating are plagiarism, cheating, falsifying information and documents (fabrication or falsification), facilitating others to do academic cheating, and lying related to work assignments.

\subsection{Sampel Data Collection}

Based on the Slovin formula with a 5\% error level with an affordable population of students majoring in accounting, 99 students are needed to be sampled in this study. To determine the sample of each class level, then a proportional random sampling technique is used(Yusuf, 2014).

\section{Result and Discussion}

Academic cheating is an effort to take the work of another person, give and get unauthorised help for their benefit. Based on the research conducted, the number of students who became the research sample and filled out the questionnaire was as many as 100 students. From the results of the questionnaire obtained, the maximum score of the academic cheating variable is 90 , and the minimum score is 36 . The total data of academic cheating variable $(\mathrm{Y})$ is 1709 . The average is 56.55 , the standard deviation (S) is 9.73, and variance (S2) is 94.61. The results of these calculations can be seen that 48 students have a high level of academic cheating or above average and as many as 52 respondents have low or below average cheating rates.

Pressure is something that arises from a need that comes from inside or outside of someone. Based on a questionnaire filled by 100 students, a maximum opportunity score is 107 , a minimum opportunity score is 62 with the total score of the $\mathrm{X}$ variable that is equal to 8681 . The average is 86.81 , the standard deviation (S) is 
8.70, and variance (S2) of 75.67. Moreover, it can be known that 68 students had a high level of pressure or above average and as much as 32 respondents have pressure that is low or below average.

Opportunities are conditions that are such that weak controls that allow fraud can occur. Based on a questionnaire filled by 100 students, the probability variable (X2) has a maximum score of 65 and a minimum score of 33. The number of probability variable scores is 5064 with an average of 50.64, a standard deviation of 7.065, and a variance of 49.909. The results of the questionnaire were collected, 57 students had a high level of opportunity or above average, and as many as 43 respondents had a low or below average chance.

The rationalisation is the process of making decisions to justify actions that are believed to be wrong but still done because they feel they will be corrected later. Based on a questionnaire filled by 100 students, the maximum opportunity score of 88 , the minimum opportunity score of 21 with the total score of the $\mathrm{X}$ variable is 6068 . The average is 60.68 , the standard deviation (S) is 10.22 , and the variance (S2) is 104.50 . Also, it can be seen that 50 students have a high level of rationalisation or above average and as many as 50 respondents have a low or below-average rationalisation.

In the regression equation, the form of influence between pressure variables, opportunities and rationalisation of academic fraud is as follows:

$$
\hat{Y}=10,019+0,219 X \_1+0,339 X \_2+0,053 X \_3
$$

Interpretation of the regression equation is a constant value (a) which is equal to 10.019 , meaning that if pressure (X1), opportunity (X2), and rationalisation (X3) have a value of 0 , then academic cheating $(\mathrm{Y})$ has a value of 10.019. Coefficient value (b1) is 0.219 , meaning that if the opportunity increases by $1 \%$, then academic cheating (Y) will increase by 0.219 assuming other independent variables remain. Coefficient value (b2) is 0.339 , meaning that if the opportunity experiences a $1 \%$ increase, and then academic cheating $(\mathrm{Y})$ will increase by 0.339 assuming other independent variables are fixed. Coefficient value (b3) is 0.053 , meaning that if the rationalisation has increased by $1 \%$, and then academic cheating $(\mathrm{Y})$ will increase by 0.053 assuming other independent variables are fixed. This is because the coefficient value of the three variables is positive.

Based on the results of multiple regression research, it can be seen that Fcount> Ftable (12,304> 2,70), which means that Ho is rejected. Therefore, it can be concluded that the pressure, opportunity and rationalisation influence simultaneously (simultaneously) on academic fraud. Next, through the $\mathrm{t}$ test for the pressure variable, $\mathrm{t}$ count $>\mathrm{t}$ table, which is $3.058>1.98498$, then Ho is rejected. So the conclusion is partial that there is a significant influence between pressure and academic fraud. Then, for the probability variable thitung $>\mathrm{t}$ table, which is 3.038>
1.98498, then Ho is rejected. That is, partially there is significant influence between opportunities with academic cheating. Furthermore, for rationalisation variables, t count $<\mathrm{t}$ table, which is $0.583<1.98498$, then Ho is accepted. That is, partially there is no significant influence between rationalisation and academic fraud.

Based on the test results of the correlation coefficient between pressure and academic fraud there is a value of 0.444 . That is, there is a moderate or not too strong a relationship between the two and has a positive direction. Thus, the higher the level of pressure, the higher the level of academic fraud and vice versa. Then, the correlation value between opportunities with academic cheating is 0.438 . That is, there is a moderate or not too strong a relationship between the two and has a positive direction. Therefore, the higher the level of opportunity, the higher the chance is also the level of academic cheating.

Furthermore, the correlation value between rationalisation and academic cheating is 0.257 . That is, there is a low or not strong relationship between the two and has a positive direction. Therefore, the higher the level of rationalisation, is also the level of academic fraud.

The relationship of pressure, opportunity and rationalisation with academic cheating has a correlation value of 0.527 . Correlation values are in the range of 0.40 to 0.599 , it can be concluded that there is a moderate or not too strong relationship between pressure, opportunity and rationalisation of academic fraud. Meanwhile, the percentage of the contribution of independent variables (pressure, opportunity and rationalisation) to the dependent variable (academic cheating) was 27.8\% while other variables influence the rest.

Based on the results of research that has been done, it can be seen that there is a partial relationship between pressure and academic fraud. These results are in line with those described by Mc Cabe (Bleeker, 2008) explaining that the pressure of competition to be able to get a good position and get a good school leads to the decision to engage in various forms of academic dishonesty. This shows that pressure can increase academic dishonesty or academic fraud.

The explanation above is reinforced by the opinion of (Bleeker, 2008) which states that several reasons why some students cheat, for example, the level of laziness, pressure, and cynicism, are difficult to conceptualise or relate to the baby boomer generation. Then (Simon, 2015) added that the pressure to win from a competency triggered errors, academic cheating, and other crimes.

The results showed that based on the results of the average score, each indicator of the pressure variable showed that the highest percentage was too difficult a test indicator with a percentage of $26.76 \%$. However, for the highest score is item number 5 with a total score of 371 where this item is a statement of a difficult and many task indicator 'the assignment is too difficult, so I copy the task of a friend who can do it". Indications indicate that in 
general, the pressure felt by students comes from tests that are too difficult. However, the form of pressure that is often felt by students is when the assignment is difficult, so they decide to do academic cheating, where the form of stress is included in many difficult and difficult task indicators.

Then, the lowest percentage was found to feel unable to meet the standards if it did not cheat, which was $22.37 \%$. The lowest score is in item number 11 with a total score of 195 "I feel satisfied with my job rather than cheating". This indication shows that in general, the lowest pressure felt by students is that they feel unable to meet the standards if they do not cheat, which is evidenced by the statement that students are satisfied with their work, where the statement is a negative statement and produces a low score. This means that students are not satisfied with their work but the score is low so the pressure from this statement is not a strong factor for students to do academic cheating

The results showed that there was a partial relationship between opportunities and academic cheating. The statement above is supported by the opinion of Bolin (Wankel, 2012) who mentions factors for predicting academic cheating include the disposition of self-control, attitudes toward academic dishonesty, and perceived opportunities for cheating. Then added by Ajzen (Nilson, 2010) which states that fraud occurs as a result of opportunity as well as the intention to cheat. Opportunities are an important part of every fraud because if the perpetrators do not have the opportunity to be known to commit fraud, then fraud is impossible to do (Albrecht, 2014).

Based on the research that has been carried out, results from the average score of each indicator from the probability variable shows that the highest percentage is the indicator that students observe their environment are also involved in cheating with a percentage of $27.16 \%$. The highest score is in item number 9 with a total score of 368 "friends don't care if they see someone cheating". This indication shows that in general the opportunities arise for students to do academic cheating because students themselves observe their environment are also involved in cheating. However, the form of opportunity that often arises is when friends who don't care about cheating.

Then, the lowest percentage was in the teacher who did not check the plagiarism action which was $23.44 \%$. The lowest score is in item number 24 with a total score of 276, where this item is a statement from the instructor indicator not changing the shape of the task or exam "the teacher gives the same task and is easy to copy". This indication shows that in general, the lowest chance that arises for students is that the teacher does not check for plagiarism. But the rare form of opportunity is the provision of the same and easily copied task from the teacher where this statement is part of the teacher's indicator does not change the form of the assignment and exam along with the conditions.

The results showed that there was no partial influence between rationalisation and academic fraud. The statement above is not in line with the opinion of (Rezaee, 2009) which states that business students justify their fraud by rationalising their actions in connection with financial scandals - then added by Mc Cabe (Anantas, 2010) which sharpens that students who cheat often rationalise their thoughts with the reason everyone does it. Finally, Payne and Nantz (Cassidy, 1999) agree that cheating is strongly related to attribution, rationalisation, reasons, and other forms of self-preservation.

Rationalisation, according to (K. Henn, 2009), is the core of the decision-making process when it's time to choose "go" or "not go" to be achieved. In this study, rationalisation does not affect because the instruments used to measure rationalisation have the lowest scores on items "schools rarely check whether students do academic cheating behaviours such as cheating, copying, lying, etc."

Based on the research that has been done, rationalisation factors, especially from the instructor indicators, do not explain what includes cheating showing a high percentage. While the highest item score of 354 is in the indicator of assessment policy or task requirements of the teacher who is unfair, in the statement "Students who have a lot of achievements and are close to the teacher are given better grades". Thus, students judge when friends who have a lot of achievements and close to the teacher get good grades and that is unfair treatment from the teacher so that their rationalisation arises to commit fraud. Meanwhile, the lowest score is in the Policy which judges that the teacher is unfair and the School does not detect academic cheating with a score of 217. The lowest score is in the statement "Schools rarely check whether students do academic dishonesty behaviours such as cheating, copying, lying, etc. "And" My teacher cares about students ", meaning that students judge that the school is enough to examine the occurrence of academic fraud so that students feel reluctant to do academic cheating. Whereas in the next statement it means that the teacher does not care about the students so they think of cheating but the level of rationalisation, for this reason, is low.

Based on the above discussion, it can be concluded that rationalisation can produce influence and can also not produce influence. Rationalisation which has a positive influence on changing academic cheating behaviour; the higher the level of rationalisation, the higher the behaviour of academic cheating is done, and vice versa - the lower the level of rationalisation, the lower the level of academic cheating behaviour. The rationalisation did not affect this study because schools had sufficiently detected and prevented academic cheating, such as when supervising the exam, most of the teachers watched closely.

\section{Conclusion}

Based on the processing of statistical data, descriptions and data analysis described in previous chapters, it can be 
concluded from this study:

1). There is a positive and significant influence between the pressure on academic cheating that is, the higher the pressure the student has, the higher the academic cheating will be.

2). There is a positive and significant influence between opportunities for academic fraud that is, the higher the opportunities students have, the higher their academic cheating will be.

3). There is no influence between the rationalisation of academic fraud. That is, rationalisation does not influence students to do academic cheating.

4). There is a positive and significant influence between pressure, opportunity and rationalisation on academic cheating. That is, together with the higher the level of pressure, opportunity and rationalisation, the higher the level of academic fraud

\section{Acknowledgements}

We are very grateful to experts for their appropriate and constructive suggestions on improving this template.

\section{REFERENCES}

[1] Albrecht, W. S. (2014). Fraud Examination. USA: Cengage Learning.

[2] Anantas, J. W. (2010). Teaching In Social Work an Educators' Guide to Theory and Pratice. USA: Columbia University Press.

[3] Anderman, E. M., \& Murdock, T. B. (2007). The Psychology of Academic Cheating. USA: Elsevier Academic Press.

[4] Antara. (2017, April 9). Jangan Asal Melarang, Beri Anak Motivasi Agar Tak Menyontek. Retrievied February 19, 2017, from https://gaya.tempo.co/read/864150/jangan-asal-melarang-b eri-anak-motivasi-agar-tak-menyontek

[5] Auer, M. E. (2017). Interactive Collaborative Learning Proceeding of the 19th ICL Conference (Vol. Vol. 1). USA: Springer International Publishing.

[6] BBC. (2015). Mahasiswa Harvard Diminta 'Bersumpah' Untuk Tidak Mencontek.

[7] Bleeker, K. C. (2008). To Be Honest Championing Academic Integrity in Community Colleges. USA: Community Colleges Press.

[8] Brow, P. M. (2012). Handbook of Prosocial Education. UK: Rowman \& Littlefield Published Inc.

[9] Cassidy, V. R. (1999). Evidence Based Teaching Current Research In Nursing Education. USA: Jones and Bartlett Publisher International.
[10] Cizek, G. J. (2010). Cheating on Test How To Do It, Detect It, and Prevent It. New Jersey: Lawrence Erlbaum Associates Inc.

[11] E. Turvey, B. (2013). Forensic Fraud Evaluating Law Enforcement and Forensic Science Cultures In The Context of Examiner Conduct. China: Elsavier Inc.

[12] Edwards., A. L. (2007). An Introduction to Liniar Regression and Correlation. New York: W.H. Freeman and Company.

[13] Emerson, R. J. (2017). Nursing Education in The Clinical Setting. USA: Elsevier Health Science.

[14] Fitriana, Annisa, \& Baridwan, Z. (2012). Perilaku Kecurangan Akademik Mahasiswa Akuntansi: Fraud Triangle. Jurnal Akuntansi Multiparadigma JAMAL, Vol. 3(No. 2), ISSN: 2086-7603.

[15] Goldmann, D. (2010). Fraud In The Markets. New Jersey: John Wiley\&Sons Inc.

[16] Halstead, J. A. (2017). Pathways to A Nursing Education Career (2nd Ed.). USA: Springer Publishing Company.

[17] IAIN LANGSA. (2016, 19 Januari). Kejujuran Modal Utama Meraih Kesuksesan. Retrievied October 14, 2017, from

http://iainlangsa.ac.id/berita/2016/01/19/852/kejujuran-mo dal-utama-meraih-kesuksesan

[18] Josephson \& Mertz. (2014, May). Changing Cheaters: Promoting Integrity and Preventing Academic Dishonesty. Retrievied December 21, 2017, from https://www.westga.edu/ jhasbun/Promoting_Integrity.pdf

[19] K. Henn, S. (2009). A Case Study Approach Business Ethics. New Jersey: John Wiley \& Sons Inc.

[20] KEMENAG. (2009). Undang-Undang Republik Indonesia Nomor 20 Tahun 2003. Retrievied October 14, 2017, from https://kemenag.go.id/file/dokumen/UU2003.pdf

[21] Kulakowski, E. C., \& Chronister, L. U. (2006). Research Administration and Management. UK: Jones\&Bartlett Publisher International.

[22] L. June, D. (2013). Protection, Security, and Safeguards Practical Approaches and Perspectives. New York: CRC Press.

[23] Mufakkir, \& Listiadi. (2016). Pengaruh Faktor yang Terdapat Dalam Fraud Triangle Terhadap Perilaku Kecurangan Akademik. Jurnal Pendidikan Akuntansi, Vol. 04(No. 3).

[24] Murdiansyah. (2017). Pengaruh Fraud Diamond Terhadap Perilaku Kecurangan Akademik (Studi Empiris pada Mahasiswa Magister Akuntansi Universitas Brawijaya). Jurnal Akuntansi Aktual, Vol. 4(No. 3), e-ISSN: 25801015 p-ISSN: 20879695.

[25] Nilson, L. B. (2010). To Improve The Academy Resource for Faculty, Instructional, and Organizational Development. USA: John Wiley \& Sons Inc.

[26] Nurfuadah, R. N. (2012). Internet Tingkatkan Kebiasaan Mencontek \& Plagiat.

[27] NWK. (2013). Ratusan Calon Pengacara Tasmania 
Ketahuan Mencontek.

[28] Oermann, M. H. (2017). Clinical Teaching Strategies in Nursing (5th Ed.). USA: Springer Publishing Company.

[29] Prasetyo, Erie. (2015, April 18), Nama Baik Jadi Alasan Sekolah Membeli Kunci Jawaban UN. Retrievied December 21, 2017), from https://news.okezone.com/read/2015/04/18/65/1136122/na ma-baik-jadi-alasan-sekolah-membeli-kunci-jawaban-un

[30] Priyatno, D. (2010). Paham Analisa Statistik Data dengan SPSS. Jakarta: Mediako.

[31] Rezaee, Z. (2009). Corporate Governance and Ethics. USA: John Wiley \& Sons Inc.

[32] Simon, R. L. (2015). Fair Play The Ethics of Sport (4th Ed.). USA: Westview Press.

[33] Singleton, T. (2006). Fraud Accounting and Forensic Accounting (3rd Ed.). USA: John Wiley \& Sons Inc.

[34] Sudjana. (2005). Metode Statistika. Bandung: Tarsito.

[35] Sugiyono. (2012). Metode Penelitian Administrasi. Bandung: Alfabeta.

[36] Sugiyono. (2015). Statistika Untuk Penelitian. Bandung: Alfabeta.

[37] Sujarwoko, Destyan. (2017, March 30). Membiasakan Hidup dengan Jujur. Retrievied December 1, 2017, from https://student.cnnindonesia.com/edukasi/2017032911280 7-445-203352/membiasakan-hidup-dengan-jujur

[38] Sulistyawati, Laeny. (2017, November 24). Lima Masalah di Sekolah yang Masih Dianggap Biasa. Retrievied December 21, 2017, from http://www.republika.co.id/Berita/Pendidikan/eduaction/17 /11/24/ozwu9s284-lima-masalah-di-Sekolah-yang-masih-d ianggap-biasa

[39] Tanayastri. (2017, June 14). Menyontek, Bagai Jarum di Karburator. Retrievied February 9, 2018, from https://student.cnnindonesia.com/edukasi/2017061412959445-221658/menyontek-bagai-jarum-di-karburator/

[40] Tipton, J. D. (2015). Personal and Professional Growth for Health Care Professionals. USA: Jones\&Bartlett Publisher International.

[41] Velaris, D. M. (2016). Handbook of Research on Academic Misconduct in Higher Education. USA: IGI Global.

[42] Wahid, Ahmad Bil. (2017, Oktober 25). Cerita BW soal Tren Koruptor Anak Muda di Kalangan Pelajar. Retrievied December 1, 2017, from https://news.detik.com/berita/d-3699194/cerita-bw-soal-tre n-koruptor-anak-muda-di-kalangan-pelajar

[43] Wankel, C. (2012). Handbook of Research Teaching Ethics in Business and Management Education. USA: IGI Global.

[44] Whitley, B. E., \& Spiegel, P. K. (2014). Academic Dishonesty An Educator's Guide. USA: Lawrence Erlbaum Associates.

[45] Yusuf, A. M. (2014). Metode Penelitian Kualitatif Kuantitatif dan Penelitian Gabungan. Jakarta: Prenadamedia Group.
[46] Zamzam, I. (2017). Pengaruh Fraud Diamond dan Tingkat Religiusitas Terhadap Kecurangan Akademik (Studi Pada Mahasiswa S-1 di Lingkungan Perguruan Tinggi Se-Kota Ternate). Jurnal Ilmiah Akuntansi Peradaban, Vol. III I (2). 